\title{
IMPLEMENTASI KEBIJAKAN REVITALISASI PASAR TRADISIONAL SARIJADI KOTA BANDUNG
}

\section{IMPLEMENTATION OF SARIJADI TRADITIONAL MARKET REVITALIZATION POLICY IN BANDUNG CITY}

\author{
Engkus ${ }^{1 *}$ \\ ${ }^{1}$ Jurusan Administrasi Publik, Fakultas Ilmu Sosial dan Ilmu Politik, Universitas Islam Negeri \\ (UIN) Sunan Gunung Djati (SGD) Bandung. Jl. A. H. Nasution 105, Bandung 40614
}

*Korespondensi: Engkus. Email: engkus@uinsgd.ac.id

(Diterima: 07-01-2020; Ditelaah: 14-02-2020; Disetujui: 05-03-2020)

\begin{abstract}
Traditional markets have a very strategic role in increasing income and employment. However, at present the competitiveness, existence and role of traditional markets are declining along with the rapid development of modern stores. The problem studied was the revitalization of traditional markets in Sarijadi Market of Bandung City. The purpose of this study was to determine the implementation of traditional market revitalization policies, constraints and efforts in traditional market revitalization policies. This study uses Merilee S. Grindle's theory, that the successful implementation of public policy is influenced by two fundamental variables, namely the content of policy and the context of implementation. The method of this study used is a qualitative descriptive approach. Data collection is done through observation, interviews, and document studies with purposive sampling technique. Data analysis used was interactive analysis, where the data reduction and data presentation components were carried out simultaneously, then the components interacted to be drawn a conclusion. Results of this study indicated the inappropriate implementation of trade facility development and management policy.
\end{abstract}

Key words: Bandung City, Policy Implementation, Traditional Market, Revitalization.

\begin{abstract}
ABSTRAK
Pasar tradisional mempunyai peranan yang sangat strategis dalam peningkatan pendapatan dan penyerapan tenaga kerja. Namun, saat ini daya saing, keberadaan dan peran pasar tradisional mengalami penurunan seiring dengan pesatnya perkembangan toko modern. Permasalahan yang diteliti adalah revitalisasi pasar tradisional di Pasar Sarijadi Kota Bandung. Tujuan dari penelitian ini adalah untuk mengetahui implementasi kebijakan revitalisasi pasar tradisional, kendala dan upaya dalam kebijakan revitalisasi pasar tradisional. Penelitian ini menggunakan teori Merilee S. Grindle, bahwa keberhasilan implementasi kebijakan publik dipengaruhi oleh dua variabel yang fundamental, yakni isi kebijakan (content of policy) dan konteks implementasi (context of implementation). Metode penelitian yang digunakan adalah pendekatan deskriptif kualitatif. Pengumpulan data dilakukan melalui observasi, wawancara, dan studi dokumen dengan teknik pengambilan sampel purposif. Analisis data yang digunakan adalah analisis interaktif, dimana komponen reduksi data dan penyajian data dilakukan secara bersamaan, selanjutnya komponen tersebut berinteraksi untuk ditarik kesimpulan. Hasil penelitian menunjukkan implementasi kebijakan pembangunan dan pengelolaan sarana perdagangan yang belum sesuai.
\end{abstract}

Kata kunci: Kota Bandung, Implementasi Kebijakan, Pasar Tradisional, Revitalisasi.

Engkus. (2020). Implementasi Kebijakan Revitalisasi Pasar Tradisional Sarijadi Kota Bandung. Jurnal GOVERNANSI, 6(1): 9-16. 


\section{PENDAHULUAN}

Pertumbuhan ekonomi suatu negara dipengaruhi oleh berbagai aspek. Indonesia sebagai negara berkembang masih memiliki potensi besar dalam mencapai pertumbuhan ekonomi yang tinggi. Pertumbuhan ekonomi salah satunya dipengaruhi oleh adanya perkembangan perekonomian. Perkembangan perekonomian Indonesia saat ini dapat dilihat dari maraknya pembangunan pusat perdagangan. Pasar sebagai salah satu bagian dari pusat perdagangan dapat dikatakan sebagai pusat pembangunan perekonomian karena dapat menciptakan lapangan pekerjaan. Dari sisi kepentingan ekonomi, semakin meningkatnya jumlah pusat perdagangan mendorong terciptanya ruang kerja bagi banyak orang (Engkus, 2019). Mulai dari jasa tenaga satuan pengamanan, pengantar barang, penjaga toko, cleaning service, hingga jasa transportasi. Ini berarti pusat perdagangan ikut serta dalam mengentaskan masalah pengangguran dan kemiskinan. Pasar merupakan suatu mekanisme yang terjadi interaksi antara penjual dan pembeli dalam menentukan harga dan melakukan pertukaran barang dan jasa. Secara fisik pusat transaksi perdagangan terbagi menjadi dua jenis, yaitu pasar tradisional dan pasar modern/ritel modern (Samuelson \& Nordhaus, 2010). Kedua jenis pasar ini memiliki perbedaan yang mencolok baik dari segi bangunan, fasilitas, maupun jenis dagangan.

Pasar tradisional mempunyai peranan yang sangat strategis dalam rangka peningkatan pendapatan dan penyerapan tenaga kerja. Untuk itu diperlukan upaya-upaya dalam rangka peningkatan daya saing pasar tradisional demi menjaga keberadaan pasar tradisional yang ada di Indonesia (Imbang, 2016) Namun, saat ini keberadaan dan peran pasar tradisional mengalami degradasi atau penurunan seiring dengan pesatnya perkembangan pasar modern. Pada hal pasar tradisional seharusnya dapat bersaing dengan pasar modern sebagai penggerak roda perekonomian. Kemudian pasar tradisional juga identik dengan lokasi perdagangan yang kurang baik, dikenal kumuh, becek, kotor, tidak teratur, tidak aman, macetnya lalu lintas, dan ketidakpastian harga. Inilah salah satu kondisi dari kemunduran tingkat kenyamanan dari pasar tradisional. Melihat kondisi pasar tradisional yang memiliki citra kurang baik, pemerintah merasa perlu adanya perubahan dan perbaikan yang dilakukan di setiap pasar tradisional. Sehingga perlu adanya pembenahan-pembenahan yang dilakukan pemerintah daerah untuk menata pasar tradisional.

Program revitalisasi pasar tradisional muncul sebagai jawaban atas citra negatif yang melekat pada pasar tradisional (Engkus, 2018). Program revitalisasi pasar tradisional juga menyentuh tata kelola (kelembagaan) pasar. Mewujudkan pasar yang profesional haruslah dikelola dengan manajemen yang terpadu dimana seluruh manajemen pasar saling bekerja sama. Kementerian Perdagangan mengembangkan program revitalisasi pasar tradisional dengan harapan dapat meningkatkan daya saing pasar tradisional dan mengembalikan pasar tradisional sebagai salah satu pusat pertumbuhan perekonomian.

Program revitalisasi pasar tradisional mulai dicanangkan pada tahun 2010 melalui Peraturan Menteri Perdagangan Nomor 03 Tahun 2010 tentang Rencana Strategis Kementerian Perdagangan 2010-2014. Renstra ini merupakan pedoman pembangunan untuk sektor perdagangan. Di dalam Renstra disebutkan bahwa arah kebijakan pembangunan dalam negeri adalah peningkatan penataan sistem distribusi nasional yang menjamin kelancaran arus barang dan jasa, kepastian usaha, dan daya saing produk domestik. Salah satu fokus prioritas adalah peningkatan jaringan distribusi untuk menunjang pengembangan logistik nasional dengan kegiatan, yaitu pengembangan sarana distribusi perdagangan melalui program revitalisasi pasar tradisional, yang saat ini berpedoman pada Peraturan Menteri Perdagangan Republik 
Indonesia Nomor 37 Tahun 2017 tentang Pedoman Pembangunan dan Pengelolaan Sarana Perdagangan. Persoalan yang kerap kali muncul adalah revitalisasi pasar tradisional ini hanya sekedar perbaikan fisik saja, pada hal sejatinya permasalahan manajemen pasar (kelembagaan) perlu diperhatikan. Karena revitalisasi tidak hanya sekedar mengubah bangunan pasar tetapi lebih dari itu. Gagalnya revitalisasi dalam merubah nasib pedagang pasar tradisional menunjukkan lemahnya manajemen pasar tradisional yang disebabkan karena pengelola pasar belum menjalankan fungsinya secara optimal dan tidak didukung dengan standard operating procedure (SOP) yang jelas, dengan kata lain membutuhkan pelayan yang prima (Suparman, 2017).

Tabel 1. Jumlah Pasar di Kota Bandung

\begin{tabular}{llcl}
\hline No. & Nama Pasar & No. & Nama Pasar \\
\hline 1 & Pasar Baru & 22 & Pasar Banceuy \\
\hline 3 & Pasar Kosambi & 23 & Pasar Palasari \\
\hline 4 & Pasar Andir & 24 & Pasar Karapitan \\
\hline 5 & Pasar Ujungberung & 26 & Pasar Cihapit \\
\hline 6 & Pasar Anyar & 27 & Pasar Gegerkalong \\
\hline 7 & Pasar Sederhana & 28 & Pasar pagarsih \\
\hline 8 & Pasar Cicaheum & 29 & Pasar Ciroyom \\
\hline 9 & Pasar Simpang & 30 & Pasar Gg Saleh \\
\hline 10 & Pasar Cihaurgeulis & 31 & Pasar Sarijadi \\
\hline 11 & Pasar Balubur & 32 & Pasar Cikaso \\
\hline 12 & Pasar Wastukencana & 33 & Pasar Kebon Sirih \\
\hline 13 & Pasar Cikapundung & 34 & Pasar Puyuh \\
\hline 14 & Pasar Moch & 35 & Pasar Basalamah \\
\hline 15 & Paha/ITC 2 & & \\
\hline 16 & Pasar Leuwipanjang & 36 & Pasar Gempol \\
\hline 17 & Pasar Ciwastra & 37 & Pasar Kota Kembang \\
\hline 18 & Pasar Sukahaji & 38 & Pasar Gedebage \\
\hline 19 & Pasar Pamoyanan & 40 & Pasar Kordon Dago \\
\hline 20 & Pasar Jatayu & 41 & Pasar Saeuran \\
\hline 21 & Pasar Sidang Serang & & \\
\hline & & & \\
\hline
\end{tabular}

Keterangan :

\begin{tabular}{|l}
\hline : dikelola PD. Pasar Bermartabat Kota Bandung \\
: dikerjasamakan dengan pihak ke-3 \\
: dihapus dari pengelolaan PD. Pasar Bermartabat \\
Kota Bandung \\
: masih berupa lahan kosong
\end{tabular}

Sumber : PD Bermartabat Kota Bandung, 2018

Pada tahun 2015, Perusahaan Daerah Pasar Bermartabat Kota Bandung merevitalisasi pasar tradisional Sarijadi. Pasar
Sarijadi berdiri sejak tahun 1985 yang terletak di Jl. Sarimanah, Sukasari, Kota Bandung. Kondisi Pasar Sarijadi seperti perkampungan kumuh dan kurang terawat, serta sudah terlihat rusak berat, sehingga pemerintah melakukan revitalisasi.

Kondisi Pasar Sarijadi sebelum dan sesudah direvitalisasi sangat berbeda yang terlihat begitu nampak adalah dari segi fisik atau bangunan Pasar Sarijadi. Pasar Sarijadi yang dahulunya terlihat kumuh dan sudah tidak layak pakai menjadi begitu tertata rapih, bersih, dan pedagang ditempatkan sesuai dengan zona dagangannya. Setelah direvitalisasi, Pasar Sarijadi memiliki luas lahan $2.983 \mathrm{~m}^{2}$ dan luas bangunan $3.000 \mathrm{~m}^{2}$ serta terdiri dari empat lantai. Pada lantai pertama diisi oleh pedagang basah, yaitu pedagang sayuran, ikan, dan daging. Kemudian, lantai dua dan tiga diisi oleh pedagang kuliner tradisional, namun di lantai tiga ditambah tempat duduk untuk bercengkrama. Sedangkan lantai empat diisi oleh kreativitas Kota Bandung, seperti lukisan, distro, dan lain-lain.

Tabel 2. Bangunan Pasar Sarijadi Setelah Direvitalisasi

\begin{tabular}{|c|c|c|}
\hline No. & Lokasi & Jenis \\
\hline 1 & Lantai Satu & $\begin{array}{l}\text { Pedagang Basah: Sayuran, Ikan } \\
\text { dan Daging }\end{array}$ \\
\hline 2 & Lantai Dua & Pedagang Kuliner Tradisional \\
\hline 3 & Lantai Tiga & $\begin{array}{l}\text { Pedagang Kuliner Tradisional dan } \\
\text { Tempat Duduk untuk } \\
\text { Bercengkrama }\end{array}$ \\
\hline 4 & $\begin{array}{l}\text { Lantai } \\
\text { Empat }\end{array}$ & $\begin{array}{l}\text { Kreativitas Kota } \\
\text { Lukisan dan Distro }\end{array}$ \\
\hline
\end{tabular}

Sumber: PD. Pasar Bermartabat Kota Bandung, 2018

Kemudian jenis ruang dagang yang terdapat di Pasar Sarijadi setelah revitalisasi terdapat ada tiga macam, yaitu toko, kios, dan meja dengan jumlah 169 ruang dagang.

Tabel 3. Jenis Ruang Dagang Pasar Sarijadi Setelah Direvitalisasi

\begin{tabular}{lcccc}
\hline \multirow{2}{*}{$\begin{array}{l}\text { Jenis } \\
\text { Ruang }\end{array}$} & Jumlah & \multicolumn{2}{c}{$\begin{array}{c}\text { Aktivasi Ruang } \\
\text { Dagang }\end{array}$} & \multirow{2}{*}{\begin{tabular}{c} 
Pedagang \\
Pemilik \\
\cline { 2 - 4 }
\end{tabular}} \\
\cline { 2 - 4 } & & Buka & Tutup & SPTB/SSTU \\
\hline Toko & 3 & 2 & 1 & 0 \\
\hline Kios & 44 & 18 & 26 & 18 \\
\hline Meja & 122 & 20 & 102 & 0 \\
\hline Jumlah & 169 & 40 & 129 & 18 \\
\hline
\end{tabular}

Sumber: PD Pasar Bermartabat Kota Bandung, 2018 
Tabel di atas menunjukkan jumlah ruang dagang yang mencapai 169 , namun masih banyak ruang dagang yang tutup. Hanya 40 ruang dagang yang masih membuka dagangannya. Hasil observasi di Pasar Sarijadi juga terlihat banyak toko dan kios yang masih tutup, khususnya di lantai dua dan tiga. Dan di lantai satu hanya ada beberapa toko dan kios saja yang buka, begitu pun dengan lantai empat hanya ada beberapa toko yang buka. Dan sisanya masih banyak toko dan kios yang digembok. Kondisi Pasar Sarijadi yang saat ini sudah memiliki bangunan yang bagus dan fasilitas yang memadai, lingkungan yang bersih, ternyata tidak membuat Pasar Sarijadi menjadi ramai pembeli atau pengunjung. Pada hal, salah satu alasan dilakukan revitalisasi adalah untuk penghidupan kembali sebuah tempat agar menjadi lebih baik.

Dengan demikian, permasalahan yang diteliti berkaitan dengan revitalisasi pasar tradisional di Pasar Sarijadi Kota Bandung. Tujuannya adalah untuk mengetahui implementasi kebijakan revitalisasi pasar tradisional, kendala dan upaya dalam kebijakan revitalisasi pasar tradisional dimaksud.

\section{MATERI DAN METODE}

\section{Konsep/Teori yang Relevan}

Merilee S. Grindle (Nawawi, 2009) mengemukakan bahwa keberhasilan implementasi kebijakan publik dipengaruhi dua variabel yang fundamental, yakni isi kebijakan (content of policy) dan konteks implementasi (context of implementation).

Variabel isi kebijakan (content of policy) yang diungkapkan Merilee S. Grindle mencakup hal-hal sebagai berikut: (1) sejauhmana kepentingan kelompok sasaran atau target groups termuat dalam isi kebijakan publik; (2) jenis manfaat yang diterima oleh target groups; (3) sejauhmana perubahan yang diinginkan oleh kebijakan; (4) apakah letak sebuah program sudah tepat; (5) apakah sebuah kebijakan telah menyebutkan implementornya dengan rinci; dan (6) sumber daya yang disebutkan apakah sebuah program didukung oleh sumber daya yang memadai.

Variabel konteks implementasi (context of implementation) mencakup halhal sebagai berikut: (1) seberapa besar kekuasaan, kepentingan, dan strategi yang dimiliki oleh para aktor yang terlibat dalam implementasi kebijakan; (2) karakteristik institusi dan rezim yang sedang berkuasa; (3) tingkat kepatuhan dan responsivitas kelompok sasaran.

Rais (2007) mengemukakan bahwa revitalisasi adalah upaya untuk menghidupkan kembali suatu kawasan atau bagian kota yang dulunya pernah hidup, akan tetapi kemudian mengalami kemunduran. Dalam proses revitalisasi suatu kawasan, aspek yang dicakup di antaranya adalah perbaikan aspek fisik, ekonomi, dan sosial.

\section{Metode}

Metode yang digunakan dalam penelitian ini adalah metode penelitian deskriptif kualitatif dengan strategi studi kasus, yang diharapkan akan didapatkan deskripsi yang jelas berkenaan dengan data dan informasi yang diperlukan dalam penelitian sehingga sinkron dengan fakta yang terjadi tanpa rekayasa (Engkus, et al., 2019).

Adapun langkah-langkah yang ditempuh dalam penelitian studi kasus ini mengambil dari pendapat (Rahardjo, 2010) sebagai berikut: (1) Pemilihan tema, topik dan kasus. (2) Pembacaan literatur. (3) Perumusan fokus dan masalah penelitian. (4) Pengumpulan data. (5) Analisis data. (6) Dialog teoritik. (7) Triangulasi temuan (konfirmabilitas). (8) Simpulan hasil penelitian.

Teknik pengumpulan data yang digunakan berdasarkan (Creswell, 1997) melibatkan empat jenis strategi, yaitu melalui observasi, wawancara, dokumentasi, dan audio-visual.

Pertama: Observasi. Observasi kualitatif menurut (Creswell, 1997) merupakan 
observasi yang di dalamnya peneliti langsung turun ke lapangan untuk mengamati perilaku dan aktivitas individu-individu di lokasi penelitian. Observasi penelitian ini memiliki empat jenis observasi. (1) Partisipan utuh dimana peneliti menyembunyikan perannya sebagai observer. (2) Peneliti sebagai partisipan dimana peneliti menampakkan perannya sebagai observer. (3) Partisipan sebagai observer dimana peran observasi sekunder diserahkan kepada partisipan. (4) Peneliti utuh dimana peneliti mengobservasi tanpa bantuan partisipan. Observasi yang dilakukan dalam penelitian ini adalah jenis peneliti sebagai partisipan, dimana peneliti menampakkan perannya sebagai observer.

Kedua: Wawancara. Wawancara kualitatif menurut Creswell (1997) menggambarkan peneliti dapat melakukan face to face interview (wawancara berhadaphadapan) dengan partisipan, mewawancari melalui telepon, atau terlibat dalam focus group interview (interview dalam kelompok tertentu) yang terdiri dari enam sampai delapan partisipan per kelompok. Wawancara-wawancara seperti ini memerlukan pertanyaan-pertanyaan yang secara umum dirancang untuk memunculkan pandangan dan opini dari para partisipan.

Ketiga: Dokumentasi. Selama proses penelitian, peneliti juga bisa mengumpulkan dokumen-dokumen kualitatif. Dokumentasi adalah teknik pengumpulan data yang tidak langsung ditujukan pada subjek penelitian, tetapi melalui dokumen. Dokumen adalah catatan tertulis yang isinya berupa pernyataan tertulis yang disusun oleh seseorang atau lembaga untuk keperluan pengujian suatu peristiwa, dan berguna bagi sumber data, bukti, informasi kealamiahan yang sukar diperoleh, sukar ditemukan dan membuka kesempatan untuk lebih memperluas pengetahuan terhadap sesuatu yang diselidiki.

Metode ini merupakan suatu cara pengumpulan data yang menghasilkan catatan-catatan penting yang berhubungan dengan masalah yang diteliti. Metode ini hanya mengambil data yang sudah ada di Pasar Sarijadi Kota Bandung, seperti profil instansi, kepegawaian, struktur organisasi, dan data lainnya yang berhubungan dengan penelitian yang dilakukan.

Penggunaan metode dokumentasi dalam penelitian mengenai "Implementasi Kebijakan Peraturan Menteri Perdagangan Republik Indonesia Nomor 37 Tahun 2017 Tentang Pedoman Pembangunan Dan Pengelolaan Sarana Perdagangan (Studi Kasus Revitalisasi Pasar Tradisional di Pasar Sarijadi Kota Bandung)", digunakan sebagai data pendukung terkait masalah penelitian. Hasil penelitian dari observasi dan wawancara, akan lebih kredibel/dapat dipercaya apabila dilengkap dengan dokumen.

Keempat: Audio dan Visual. Data dalam audio visual ini dapat berupa foto, objek-objek seni, videotape atau segala jenis suara atau bunyi. Metode ini bisa menjadi metode yang tidak terlalu menonjol dalam proses pengumpulan data.

Teknik analisis data yang digunakan dalam penelitian ini adalah analisis kualitatif. Matthew B. Milles dan A. Michael Hubberman dalam (Sugiyono, 2009) mengemukakan bahwa aktivitas dalam analisis data kualitatif dilakukan secara interaktif dan berlangsung secara terus menerus sampai tuntas, sehingga datanya sudah jenuh. Aktivitas analisis data dimaksud mencakup data reduction, data display, dan conclusion drawing verification.

\section{HASIL DAN PEMBAHASAN}

Implementasi kebijakan revitalisasi pasar tradisional Sarijadi Kota Bandung berdasarkan Peraturan Menteri Perdagangan Republik Indonesia Nomor 37 Tahun 2017 tentang Pedoman Pembangunan dan Pengelolaan Sarana Perdagangan menggambarkan hal-hal sebagai berikut:

Pertama: Isi Kebijakan (Content of Policy). Yang pertama sekali dilihat dalam implementasi kebijakan adalah isi kebijakan (content of policy). 


\section{1) Kepentingan Kelompok Sasaran}

Berdasarkan hasil wawancara yang peneliti lakukan, dapat diambil kesimpulan bahwa kebijakan program revitalisasi target group/masyarakat termuat dalam isi kebijakan, dimana revitalisasi pasar memang ditujukan untuk kesejahteraan pedagang Pasar Sarijadi. Hal tersebutlah kemudian yang menjadi dasar dan patokan pelaksanaan program ini. Sehingga dalam semua tahapan, para pedagang Pasar Sarijadi yang menjadi perhatian utama.

\section{2) Tipe Manfaat}

Melihat hasil wawancara yang telah dilakukan dengan semua informan, peneliti menyimpulkan bahwa pada indikator ini manfaat yang diperoleh belumlah sesuai dengan aspek-aspek yang seharusnya terpenuhi, yaitu manfaat secara fisik/ bangunan, manajemen, ekonomi dan sosial budaya.

\section{3) Derajat Perubahan yang Diinginkan}

Berdasarkan hasil wawancara, peneliti menyimpulkan bahwa implementasi program revitalisasi pasar pada indikator ini belumlah terlaksana secara optimal, karena perubahan yang dicapai belum sesuai dengan aspek yang seharusnya, yaitu aspek fisik/bangunan, manajemen, ekonomi, dan sosial budaya.

\section{4) Letak Pengambilan Keperluan}

Berdasarkan hasil wawancara, peneliti menyimpulkan bahwa informan tidak mengetahui secara pasti mengapa program revitalisasi dilakukan di Pasar Sarijadi. Menurut informan, implementasi revitalisasi pasar tradisional Sarijadi kurang tepat, karena letak geografis yang kurang strategis. Selain itu, informan menganggap bahwa hal ini terutama berkaitan dengan adanya kebijakan politik yang dilakukan sehingga Pasar Sarijadi dipilih untuk dilakukan revitalisasi.

\section{5) Pelaksana Program}

Berdasarkan hasil wawancara dengan informan, peneliti menyimpulkan kurangnya komunikasi di antara pengelola dan para pedagang. Hal ini menyebabkan implementasi revitalisasi Pasar Sarijadi kurang berjalan optimal apabila dilihat berdasarkan indikator pelaksana program. Pelaksana program belum bekerja secara optimal dalam melaksanakan kebijakan revitalisasi pasar tradisional.

\section{6) Sumber Daya yang Dilibatkan}

Berdasarkan hasil wawancara dengan sejumlah informan, peneliti menyimpulkan bahwa revitalisasi pasar tradisional Sarijadi dalam indikator sumber daya sudah berjalan cukup baik. Sumber daya yang dibutuhkan untuk melaksanakan kebijakan revitalisasi pasar tradisional di Pasar Sarijadi sudah memadai. Sumber daya pendukung lain juga sudah berjalan dengan baik.

Kedua: Konteks Implementasi (Context of Implementation). Yang kemudian dilihat dalam implementasi kebijakan adalah konteks implementasi. Dalam hal ini, konteks implementasi berhubungan dengan lingkungan kebijakan, yaitu lingkungan dimana kebijakan diimplementasikan.

\section{1) Kekuasaan, Kepentingan dan Strategi dari Aktor yang Terlibat}

Berdasarkan hasil wawancara dengan informan, peneliti menyimpulkan bahwa implementasi program revitalisasi pasar berhubungan dengan strategi pemasaran mengenai pasar itu sendiri sehingga Pasar Sarijadi dapat lebih dikenal oleh kelompok sasaran, dalam hal ini masyarakat.

\section{2) Karakteristik Lembaga dan Rezim yang Berkuasa}

Berdasarkan hasil wawancara dengan informan, peneliti menganalisis bahwa kinerja pengurus Pasar Sarijadi selaku pengelola belumlah sampai kepada aspek manajemen pemasaran dari Pasar Sarijadi, karena setelah dilakukannya revitalisasi Pasar Sarijadi bertambah sepi pengunjung.

3) Tingkat Kepatuhan dan Adanya Respons dari Pelaksana

Berdasarkan hasil wawancara, peneliti menyimpulkan bahwa pengurus Pasar 
Sarijadi selaku pelaksana program memberikan respons yang cepat tanggap apabila terjadi keluhan atau masalah yang ada di Pasar Sarijadi. Jika tidak direspons dengan cepat, dapat menimbulkan masalah yang semakin besar.

Kendala yang dihadapi dalam implementasi kebijakan revitalisasi pasar tradisional Sarijadi Kota Bandung berdasarkan Peraturan Menteri Perdagangan Republik Indonesia Nomor 37 Tahun 2017 tentang Pedoman Pembangunan dan Pengelolaan Sarana Perdagangan dapat digambarkan sebagai berikut:

1) Ditinjau dari dimensi isi kebijakan terdapat permasalahan pada indikator tipe manfaat, dimana manfaat yang diterima oleh pedagang Pasar Sarijadi tidak sesuai dengan rencana awal revitalisasi Pasar Sarijadi. Implementasi kebijakan revitalisasi tidak membawa manfaat pada bidang ekonomi pedagang. Pedagang Pasar Sarijadi hanya merasakan manfaat dari segi bangunan dan fasilitas, sedangkan dari segi pendapatan pedagang tidak memperoleh kenaikan serta mengalami penurunan konsumem atau pembeli. Banyak pedagang yang gulung tikar disebabkan pendapatan terus menurun sehingga modal usaha habis tanpa balik modal. Dengan demikian, kendala dalam revitalisasi pasar tradisional di Pasar Sarijadi berdasarkan indikator tipe manfaat terletak pada tidak berubahnya keadaan ekonomi pedagang setelah dilakukannya revitalisasi pasar. Manfaat yang diperoleh pedagang hanya mendapatkan manfaat secara fisik/bangunan pasar.

2) Dilihat dari derajat perubahan yang diinginkan, maka perubahan yang dirasakan pedagang setelah revitalisasi Pasar Sarijadi membuat jumlah pembeli semakin menurun jika dibandingkan dengan sebelum dilakukannya revitalisasi pasar. Hal ini disebabkan karena harga jual di Pasar Sarijadi yang dikhawatirkan lebih mahal dibanding harga pasar lainnya, serta adanya dua pasar dalam satu wilayah yang sama sehingga masyarakat lebih memilih pasar lain dibandingkan untuk membeli di Pasar Sarijadi.

3) Dalam indikator pelaksana program, kendala yang terjadi adalah kurangnya komunikasi dan koordinasi dari pengelola sehingga program yang ada belum dilaksanakan secara optimal. Hal ini tidak akan terjadi apabila pengelola melakukan sharing pendapat atau diskusi bersama pedagang sehingga tujuan kebijakan dalam revitalisasi Pasar Sarijadi dapat tercapai.

4) Sedangkan untuk dimensi konteks implementasi, kendala terletak pada indikator karakteristik lembaga dan rezim yang berkuasa, dimana kinerja pengurus Pasar Sarijadi masih belum optimal dalam menjalankan tugasnya.

\section{KESIMPULAN DAN REKOMENDASI}

\section{Kesimpulan}

Penelitian ini menyimpulkan hal-hal sebagai berikut:

1) Implementasi kebijakan revitalisasi pasar tradisional Sarijadi Kota Bandung berdasarkan Peraturan Menteri Perdagangan Republik Indonesia Nomor 37 Tahun 2017 tentang Pedoman Pembangunan dan Pengelolaan Sarana Perdagangan diukur dengan teori implementasi kebijakan dari Merilee S. Grindle belum sesuai dengan peraturan yang ada. Kebijakan revitalisasi yang dilakukan di Pasar Sarijadi cenderung menekankan aspek fisik, yaitu pembangunan gedung pasar. Sedangkan aspek-aspek nonfisik yang menekankan manajemen, ekonomi dan sosial budaya belum dilakukan secara optimal. Akibatnya revitalisasi pasar tidak menambah baik minat pedagang dan pembeli untuk berniaga di Pasar Sarijadi.

2) Kendala yang dihadapi dalam implementasi kebijakan revitalisasi pasar tradisional Sarijadi Kota Bandung 
berdasarkan Peraturan Menteri Perdagangan Republik Indonesia Nomor 37 Tahun 2017 tentang Pedoman Pembangunan dan Pengelolaan Sarana Perdagangan diukur dengan teori implementasi kebijakan dari Merilee S. Grindle terletak pada tipe manfaat, derajat perubahan yang diinginkan, dan pelaksana program dalam dimensi isi kebijakan, sedangkan dalam dimensi konteks implementasi, terletak pada karakteristik lembaga dan rezim yang berkuasa, yaitu belum optimalnya kinerja pengurus Pasar Sarijadi.

\section{Rekomendasi}

Revitalisasi pasar seyogyanya direncanakan secara komprehensif, gradual (bertahap/pilot project) dan terintegrasi mulai dari pemerintah pusat, provinsi kabupaten/ kota, dan pelibatan dunia usaha/pedagang serta masyarakat sekitar dengan sharing budgetting (pemerintah, dunia usaha dan pedagang). Seiring dengan itu dilakukan penguatan manajemen pasar yang modern, penguatan/hubungan hukum antara pemerintah (Badan Usaha Milik Daerah) dan pedagang sehingga tercipta harmonisasi dan humanitas.

\section{DAFTAR PUSTAKA}

Creswell, J. W. (1997). Qualitative Inquiry and Research Design, Choosing Among Five Traditions. California: SAGE Publications, Inc.

Engkus. (2018). "Komitmen Pemerintah Daerah Dalam Pembangunan Pasar Tradisional Di Wilayah Metropolitan Bandung Provinsi Jawa Barat". Kelola, 1(1): 105-130.

Engkus. (2019). "Pengaruh Kualitas Pelayanan Terhadap Kepuasan Pasien Di Puskesmas Cibitung Kabupaten Sukabumi". Jurnal GOVERNANSI, 5(2): 99-109.

Engkus; Suparman, Nanang; Trisakti, Fadjar \& Rodhiya, Mohammad Robby.
(2019). "Implementasi Keterbukaan Informasi Publik Di Universitas Islam Negeri Sunan Gunung Djati Bandung". Jurnal GOVERNANSI, 5(1): 24-46.

Imbang, S. (2016). Analisis Faktor-faktor Yang Mempengaruhi Tingkat Pendapatan Pedagang Kaki Lima Kota Surakarta Tahun 2015. Semarang: Fakultas Ekonomi Universitas Negeri Semarang.

Nawawi, I. (2009). Public Policy, Analisis, Strategi Advokasi Teori Dan Praktek. Surabaya: Putra Media Nusantara (PMN).

Rahardjo, M. (2010). "Jenis Dan Metode Penelitian Kualitatif". http://mudjia rahardjo.com/materi-kuliah/215jenis-dan-metode-penelitiankualitatif.html.

Rais, A. (2007). Pengaruh Air Payau Terhadap Beton Yang Memakai Semen Padang Di Kota Padang Sumatera Barat. Medan: Universitas Sumatera Utara.

Samuelson, Paul A. \& Nordhaus, William D. (2010). Ilmu Ekonomi Mikro. Jakarta: Media Global Edukasi.

Sugiyono. (2009). Metode Penelitian Kualitatif. Bandung: Alfabeta.

Suparman, N. (2017). "Kualitas Pelayanan Izin Mendirikan Bangunan (IMB) Pada Badan Pelayanan Perizinan Terpadu Dan Penanaman Modal Kabupaten Cianjur". Jurnal Administration, 13(1): 1-8. 